\title{
MULTIDISCIPLINARY, INTERDISCIPLINARY, AND TRANSDISCIPLINARY (MIT) LEARNING APPROACH AND STRATEGY BASED ON INDONESIAN NATIONAL QUALIFICATION FRAMEWORK (KKNI) CURRICULUM
}

\section{Agus Zaenul Fitriia, Muntahibun Nafis ${ }^{2}$, Luluk Indarti ${ }^{3}$ \\ Institut Agama Islam Negeri (IAIN) Tulung Agung \\ Email: 1'guszain@yahoo.co.id; ${ }^{2}$ muntahibunnafis@gmail.com; \\ ${ }^{3}$ lulukhamdani@gmail.com. ${ }^{1 a}$ Coresponding author}

\begin{abstract}
Inadequate understanding and different perspectives of Islamic higher education (PTKIN) in Indonesia particularly the graduate schools towards Multidisciplinary, Interdisciplinary, and Transdisciplinary (MIT) approaches result in ineffective implementation of Indonesian National Qualification Framework/Kerangka Kualifikasi Nasional Indonesia (KKNI) curriculum. Yet, MIT approach is highly needed to accelerate state development. MIT study has integrated character which opens to new developments of science and methodology and will possibly create new knowledge hybrids. This research investigated MIT learning strategy and approach at graduate schools of UIN Syarif Hidayatullah Jakarta, UIN Sunan Kalijaga Yogyakarta, and UIN Maulana Malik Ibrahim Malang. The policy of MIT learning aims to enable the learning process at graduate schools to produce new comprehensive discoveries on science and humanities. Based on a qualitative research method, this showed that the graduate schools had different MIT approach and strategy in learning and this was greatly influenced by lecturer's and decision maker's paradigms. MIT approach was chosen respond to the nature of science, realize very complex issues, synergize various disciplines of sciences, motivate multi-sector expert collaboration, and produce new products. In short, MIT practices mean collaboration and synergy among involving people either experts with non-experts or academic with non-academic staff.
\end{abstract}

Keywords: approach, strategy, interdisciplinary, multidisciplinary, transdisciplinary, learning.

DOI: http://dx.doi.org/10.20414/ujis.v24i1.375 


\section{Introduction}

THE DYNAMIC SHIFT and development in human's life lead to numerous new complex problems which demand mindset shift and innovation to survive and bequeath their culture. The developments are further impacted on curriculum and teaching shift of particularly Graduate Schools that aim at producing graduates enable to discover and develop knowledge, science, and technology.

A Solution in the complexity needs to be viewed in perspective of complexity theory. Complexity theory utilized as a theoretical perspective that can generate holistic study in the process of change during the project. ${ }^{1}$ Complexity features include uncertainty, multi-perspective, and interconnected. This shows the existence of natural law (sunnatullahh) on complexity issues encountered by humans that can not only be explained by one discipline of science but a combination of various disciplines of science. Complexity theory derived from the concept developed in computer science to solve problems using more than just certain Algorithm approach in 1930s. This indicates that complex problems faced by humans today can not only be overcome by one discipline but multidiscipline of science. In fact, the synergy from multi-discipline of science is required in the application of science and technology. For instance, seat safety and convenience today are the results from cooperation and synergy of Physics, Ergonomy, Mathematics, and others. ${ }^{2}$

In the perspective of Islamic education, the aim of education is not only to produce high intellectual people, but also profound spirituality to create people with strong not a split personality, those who possess lack of spirituality. Both intellectuality and spirituality must match without any dichotomy to achieve the goal

${ }^{1}$ Phil Wood and Graham Butt, "Exploring the Use of Complexity Theory and Action Research as Frameworks for Curriculum Change," Journal of Curriculum Studies 46, no. 5 (September 3, 2014): 676-696, accessed February 6, 2020, https://doi.org/10.1080/00220272.2014.921840.

2 Uwes A. Chaeruman, "Memahami Konsep Trandisiplineritas dan Pendidikan Trandisipliner" (Paper presented at the Philosophy course at Doctorate degree of Education Technology, Graduate Program, State University of Jakarta, Jakarta, December 2010), 23-24. 
of being perfect persons. Three State Islamic Universities (UIN) including UIN Jakarta, UIN Yogyakarta, and UIN Malang with their science and religion integration, become new hopes in developing Islamic education in Indonesia. These universities are expected to be able to create educational products in the form of polymath persons. Polymath is defined as someone with expertise in diverse major subjects; such a person is known to illustrate complex knowledge to solve certain problems. Polymath persons are very creative and competent in Mathematics, poems, and Philosophy that are rarely possessed by common people. ${ }^{3}$ In the history of Islamic civilization, Al-Biruni and Ibn Hazm are considered as polymath persons, since both have the capability to write in various disciplines. ${ }^{4}$ One of the efforts to solve the problems above is using MIT approach in learning. This approach is flexible and able to reach almost all subject of knowledge. Therefore, the chance to obtain solution for diverse social science problems is open and effective.

Learning approaches determined in KKNI curriculum are Multidisciplinary, Interdisciplinary, and Transdisciplinary (MIT). First is multidisciplinary. This approach involves at least two disciplines of science as solutions for certain problems through education, research, and community service. Multidisciplinary approach means the effort to integrate some disciplines to solve particular issues. ${ }^{5}$ The main feature of this approach is the involvement of many sciences within the same group of knowledge. ${ }^{6}$ The use of science in learning process is based on

${ }^{3}$ Robert Root-Bernstein and Michele Root-Bernstein, "Artistic Scientists and Scientific Artists: The Link Between Polymathy and Creativity," in Creativity: From Potential to Realization, ed. R. J. Sternberg, E. L. Grigorenko, and J. L. Singer (Washington, DC, US: American Psychological Association, 2004), 127-151.

${ }^{4}$ Chase S. Robinson, Para Pembentuk Sejarah Peradabah Islam Seribu Tahun Pertama, 1st ed. (Ciputat: Pustaka Alvabet, 2019), 138.

5 A.E. Prentice, "Introduction," in Information Science-The Interdisciplinary Context, ed. J.M. Pemberton and A.E. Prentice (New York: Neal-Schumen Publisher, 1990), 23.

${ }^{6}$ Setya Yuwana Sudikan, "Pendekatan Interdisipliner, Multidisipliner, dan Transdisipliner dalam Studi Sastra," Paramasastra 2, no. 1 (March 1, 2015): 4, accessed July 6, 2020, https://journal.unesa.ac.id/index.php/paramasastra/ article/view/1496. 
interrelated sciences. Various disciplines of science can be utilized to solve problems since complex problems can be overcome by various perspectives. Multidiscipline approach is an effort to integrate some disciplines to solve certain problems. ${ }^{7}$

Second is interdisciplinary. This approach combines two disciplines of science to create a certain method. ${ }^{8}$ Another definition of interdisciplinary approach is an approach employing various perspectives of a relevant or integrated group of science to solve a certain problem. Thus, interdisciplinary shows intensive interaction between one or more disciplines, either relating directly or not, through teaching and research program to integrate the concept, methods, and analysis. The term interdisciplinary, according to Louis d'Hainaut, is not a scientific term with a unique definition and accepted universally. ${ }^{9}$ The content of this concept might be interpreted distinctively and some texts on this study frequently encountered great numbers of terms introducing different interpretations, which are not always in the same dimension or even sometimes tend to be contradictory.

The third is transdisciplinary. Transdisciplinary approach gathers collective knowledge to solve greater and complex problems. This approach attempts to develop a new theory or axioma by relating various disciplines and the involvement of non-experts to obtain a conclusion and policy. This approach is utilized to reach targets, including how to encounter complexities of reality, how to understand complex global issues, how to promote synergy among disciplines, and how to build cooperation among experts from various sectors. ${ }^{10}$ The implementation of this

\footnotetext{
7 Prentice, "Introduction," 23.
}

8 A.G.M. van Melesen, Ilmu Pengetahuan dan Tanggungjawab Kita, trans. K Bertengs (Jakarta: Gramedia, 1985); M. Amin Abdullah et al., Praksis Paradgima Integrasi-Interkoneksi dan Transfomasi Islamic Studies of UIN Sunan Kalijaga (Yogyakarta: PPs UIN Sunan Kalijaga Press, 2014), 72-73.

9 Louis d'Hainaut, "International Symposium on Interdisciplinarity in General Education" (Presented at the Unesco Headquarters from 1 to 5 July 1985, Unesco Headquarters, 1986), 9-12.

10 Batmang, "Pendekatan Transdisipliner (Suatu Alternatif Pemecahan Masalah Pendidikan)," Al-TA'DIB 9, no. 2 (July 1, 2016): 48, accessed March 30, 2020, http://ejournal.iainkendari.ac.id/al-tadib/article/view/512. 
approach is to discover and find comprehensive solutions to new or unforeseen problems.

Referring to the above reasons, the writers considered research on MIT learning approach is worth doing, especially at graduate schools of Islamic Higher Education (IHE) that have promoted the integration of science and the implementation of KKNI curriculum, ${ }^{11}$ determined by the government.

Based on this context, this research focused on MIT approach and strategy implemented by three graduate schools of UIN Jakarta, UIN Yogyakarta, and UIN Malang. This research belonged to qualitative study using phenomenology approach to describe, discover meanings, and explain unique and interesting phenomena from these three universities. This study was multisites field research. ${ }^{12}$ The data collecting methods used included in-depth interview, participation observation, and documentation study. ${ }^{13}$ This study adopts Miles and Huberman's inductive techniques to analyze the data, which include reduction, display, and conclusion. ${ }^{14}$

\section{MIT-based Thematic Course Integration}

Thematic course was used to implement MIT approach in the learning process at UIN Jakarta. The MIT courses include: (1) Laws, Medical Ethics, and Health, (2) Da'wah, Cultural Communication, and Politics, (3) Islamic Economics in the Muslim World: A Comparative Study. ${ }^{15}$ This strategy aimed to enable

11 Precidential Regulation (Perpres) No. 8 of 2012 on Indonesian National Qualification Framework (Kerangka Kualifikasi Nasional Indonesia/KKNI), 2012 chapter 1 article 1; See also article 1 point (5) Regulation of the Ministry of Research and Technology, Higher Education Directory (Permenristekdikti) No. 44 of 2015 on Higher Education National Standard (Standar Nasional Pendidikan Tinggi/SNPT), 2015.

12 Robert Bogdan, Participant Observation in Organizational Setting (New York: Syracuse University Press, 1972), 22.

${ }^{13}$ Robert Bogdan and S.J. Taylor, Pengantar Metode Penelitian Kualitatif, trans. Arief Furchan (Surabaya: Usaha Nasonal, 1992), 65.

14 Matthew B. Miles, A. Michael Huberman, and UI Team, Analisis Data Kualitatif, 1st ed. (Jakarta: Universitas Indonesia, 1992), 15-16.

15 Graduate School Academic Handbook 2015-2019 (UIN Syarif Hidayatullah Jakarta, 2015), 41. 
students from different background to attend such courses. Furthermore, lecturers from various disciplines of science would able to teach those courses. They believed that MIT approach would only be able to be implemented effectively in multidiscipline courses.

At UIN Yogyakarta, MIT approach could be found at elective courses such as (1) Agama dan Teori-teori Sosial (Religion and Social Theories), (2) Islam dan Kajian-kajian Budaya (Islam and Cultural Studies), and (3) Islam dan Kajian Sosio-Legal (Islam and Socio-Legal Studies). ${ }^{16}$ In contrast to UIN Malang, MIT features could not be seen either in the compulsory or elective courses, so that monodiscipline courses dominate its postgraduate curriculum. This might be caused that UIN Malang did not provide Interdisciplinary Islamic Studies program which discusses various fields of study.

These MIT-based thematic courses were related to issues discussed by most people. Such themes were the materials discussed by the students in various perspectives depending on their background of knowledge. In the discussion on democration, for example, arguments come from students of tafsir, politic, law, and health backgrounds; and this leads to lively discussion and enriches students' discourse and perspectives. Some courses reflecting collaboration of various disciplines showed a strong study on interdiscipline rather than the multidiscipline and transdiscipline ones, because the lecturers had different group and background of expertise. This is in line to Val Melesen's argument that interdisciplinary approach is collaboration study between one to another discipline to create a certain method. ${ }^{17}$ Furthermore, this approach attempts to solve a particular problem using the perspective of integrated relevant or appropriate group of science. Therefore, interdisciplinary approach indicates an intensive interaction between one or more disciplines, directly or indirectly, through teaching and research programs to achieve integrated concept, method, and analysis.

${ }^{16}$ Academic team, "Kurikulum," PPS UIN Sunan Kalijaga, accessed February 6, 2020, http://pps.uin-suka.ac.id/id/akademik/kurikulum.html.

${ }^{17}$ van Melesen, Ilmu Pengetahuan, 72-72. 
The strategy applied by UIN Yogyakarta was different from UIN Jakarta that lecturers of non-education background were in charge of teaching education courses in order that students obtain distinct perspectives from the materials discussed in the course. Similar to UIN Yogyakarta, UIN Malang also employed the same strategy in the curriculum and its implementation.

\section{Team Teaching as MIT Study Reinforcement}

MIT approach, in fact, must be part of graduate school programs for masters or P.hD, as stated in the Presidential Regulation No. 8 of 2012 on Indonesian National Qualification Framework/Kerangka Kualifikasi Nasional Indonesia (KKNI). KKNI is a framework of competency qualification level to match, equalize, and integrate education, vocational training, and working experience to provide competence recognition based on the work structures in various sectors. ${ }^{18}$ Qualification is an achievement on learning outcomes within KKNI.

As formulated in KKNI, there are 9 levels of education, undergraduate level/ S1/D4 is $6^{\text {th }}$ level, postgraduate level/S2 is $8^{\text {th }}$, whereas doctorate degree/ S3 is level 9. The following table will show detail explanation on these levels:

Table 1: differences in the learning outcomes of $6^{\text {th }}, 8^{\text {th }}$, and $9^{\text {th }}$ levels

\begin{tabular}{|c|c|c|}
\hline Level 6 (Strata-1) & Level 8 (Strata-2) & Level 9 (Strata-3) \\
\hline $\begin{array}{l}\text { Capable of applying } \\
\text { their expertise and } \\
\text { making use of } \\
\text { technology in their } \\
\text { field to solve } \\
\text { problems and are able } \\
\text { to adapt to a new } \\
\text { situation. }\end{array}$ & $\begin{array}{l}\text { - Capable of developing } \\
\text { knowledge, } \\
\text { technology, and or art } \\
\text { within their field of } \\
\text { study or professional } \\
\text { practice through } \\
\text { research, to produce } \\
\text { innovative and } \\
\text { verified works. }\end{array}$ & $\begin{array}{l}\text { - Capable of developing } \\
\text { new knowledge, } \\
\text { technology, and or art } \\
\text { within their field of } \\
\text { study or professional } \\
\text { practice through } \\
\text { research, to produce } \\
\text { creative, original, and } \\
\text { verified works. }\end{array}$ \\
\hline - Mastering general & - Capable of solving & - Capable of solving \\
\hline
\end{tabular}

18 Precidential Regulation (Perpres) No. 8 of 2012 on Indonesian National Qualification Framework (Kerangka Kualifikasi Nasional Indonesia/KKNI) chapter 1 article 1; See also article 1 point (5) Regulation of the Ministry of Research and Technology, Higher Education Directory (Permenristekdikti) No. 44 of 2015 on Higher Education National Standard (Standar Nasional Pendidikan Tinggi/SNPT). 


\begin{tabular}{|c|c|c|}
\hline $\begin{array}{l}\text { theoretical concept of } \\
\text { particular science and } \\
\text { particular theoretical } \\
\text { concept of the science } \\
\text { deeply, and are able } \\
\text { to formulate } \\
\text { procedural problem } \\
\text { solving. }\end{array}$ & $\begin{array}{l}\text { problems on science, } \\
\text { technology, and or art } \\
\text { at their field of study } \\
\text { through inter or multi- } \\
\text { disciplinary approach. }\end{array}$ & $\begin{array}{l}\text { problems on science, } \\
\text { technology, and or art } \\
\text { at their field of study } \\
\text { through inter, multi, or } \\
\text { trans-disciplinary } \\
\text { approach. }\end{array}$ \\
\hline $\begin{array}{l}\text { Capable of make the } \\
\text { right decision based } \\
\text { on data and } \\
\text { information analysis } \\
\text { and are able to } \\
\text { provide guidance to } \\
\text { choose alternative } \\
\text { solution individually } \\
\text { or in groups. }\end{array}$ & $\begin{array}{l}\text { - Capable of manage } \\
\text { research and } \\
\text { development benefited } \\
\text { society and science, } \\
\text { and are able to gain } \\
\text { national or } \\
\text { international } \\
\text { recognition. }\end{array}$ & $\begin{array}{l}\text { - Capable of manage, } \\
\text { lead, and develop } \\
\text { research and } \\
\text { development benefited } \\
\text { humans and science, } \\
\text { and are able to gain } \\
\text { national or } \\
\text { international } \\
\text { recognition. }\end{array}$ \\
\hline $\begin{array}{l}\text { Responsible for their } \\
\text { own works and can be } \\
\text { given responsibility } \\
\text { for organization } \\
\text { achievement. }\end{array}$ & - & - \\
\hline
\end{tabular}

Based on table 1 above, the main distinction of learning outcomes among the three levels is the aspect of mastering theoretical and methodological concepts to be applied in research and learning. Undergraduate student at level 6 is only required to be able to master theoretical concept based on monodiscipline approach; whereas postgraduate students at level 8 have to be capable of solving problems and develop the theoretical concepts based on inter-multi-disciplines research. Meanwhile, doctoral students (level 9) are required to be able to produce original works based on inter-multi-trans-disciplinary research, to be able to produce nationally or internationally reputable works. Therefore, graduate school graduates are expected to be able to solve complex problems in their expertise. Various disciplines of science interrelatedly complete the sciences which continue to grow.

UIN Jakarta, UIN Yogyakarta, and UIN Malang utilized team teaching strategy to implement MIT approach within their curriculum. MIT approach means a process the learning involving various disciplines in order that students will be able to solve their 
problems from various perspectives of different sciences. If the multidisciplinary is done by assigning lecturers from similar group of science to teach at certain study programs on a faculty, then the multidisciplinary approach refers to various perspectives of relevant sciences. Furthermore, multidisciplinary approach is the development of discipline with assistance from other sciences, such as politics, economy, management, social, and others. ${ }^{19}$ The involvement of more than two different sciences is highly suggested in analysing the same issue. The multidisciplinary learning strategy implementation is illustrated in figure 01 below.

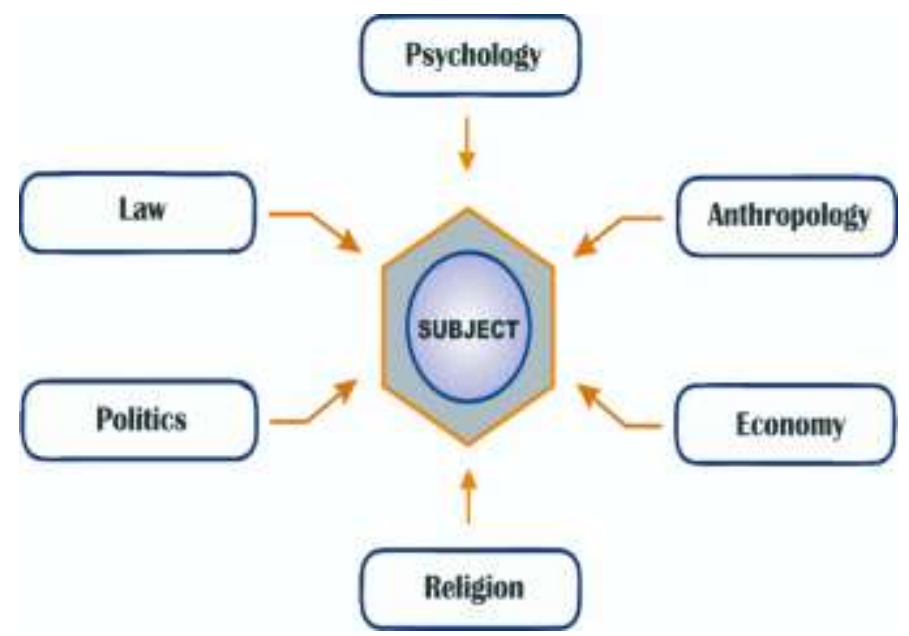

Figure 01: Multidisciplinary Approach in Team Teaching

The aim of multidisciplinary learning strategy is to build multi-perspectives in order to open students' knowledge insight from more than only monodiscipline science. Thus, motivation in the process of learning is the key to lead the learning activities. ${ }^{20}$ Learning process will run easily when students have intrinsic or

19 Rosdiana A. Bakar, “Konsep Pendidikan Muhammad Quthb," Ihya' Al'Arabiyyah 5, no. 1 (2015): 26, http://ejournalpba.org/index.php/ihya/article/ view/2/2.

20 Pakhur Razi, "Hubungan Motivasi dengan Kerja Ilmiah Siswa dalam Pembelajaran Menggunakan Virtual Laboratorium Kelas X SMAN Kota Padang," Jurnal Informasi dan Pendidikan 6, no. 2 (2013): 120. 
extrinsic motivation, due to their interest and awareness on the importance of learning.

Interdisciplinary approach was implemented by crossing lecturers from different study programs and faculties to have more profound interdisciplinary discussions since interdisciplinary study requires the involvement of one and another science with a certain method. ${ }^{21}$ Interdisciplinary approach is further employed to solve problems using various perspectives from an integrated relevant group of sciences, so that interdisciplinary approach shows intensive interaction among disciplines, in direct relationship or not, through teaching and research programs, aiming to integrate the concept, method, and analysis. This approach can be utilized to attract the spirit and interest in the process of learning due to its relevance to today's reality. Moreover, this approach can also be a solution to the global issues from various perspectives. The implementation of interdisciplinary approach in the learning strategy is shown in figure 02 as follows.

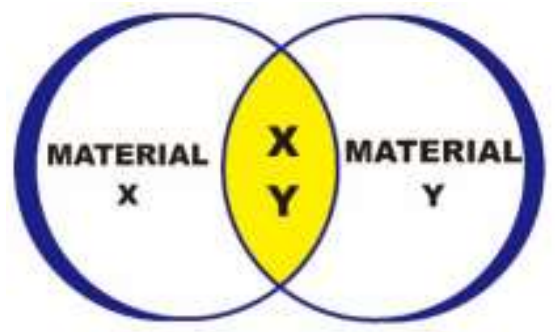

Figure 02: Interdisciplinary Approach in Team Teaching

According to G. Vaideanu, ${ }^{22}$ there are several classifications of interdisciplinary approach. Interdisciplinary level depends on the influence given by each discipline involvement. Dominant influence from one discipline is not good, but balance influence will show good quality.

${ }^{21}$ van Melesen, Ilmu Pengetahuan, 72-73.

22 G. Vaideanu and Unesco-CEPES, Interdisciplinarity In Higher Education (Bucharest: Unesco-CEPES, 1983), 22. 
Transdisciplinary approach harnesses collective knowledge to overcome greater and complex problems. Its main feature is the multidisciplinary integration utilized to discuss complex problems. The application of this approach indicates "cooperation" and synergy between people and the sectors involved in it. Transdiscipline shows qualitative and qualitative synergy. The findings from results UIN Jakarta, UIN Yogyakarta dan UIN Malang show that they have not been able to implement transdisciplinary approach due to the difficulty in involving nonexperts into research and scientific discussion. Non-experts tend to be not actively involved as the subjects but the objects of study and research.

Transdisciplinary approach is employed for some targets, including: (1) how to respond to reality of science, (2) how to realize complex issues, (3) how to synergize various disciplines of science, and (4) how to motivate the collaboration of experts from various sectors. Transdiscipline in practice means cooperation or synergy among involving people. The implementation of transdiscipline aims to achieve a qualified thing. ${ }^{23}$ The description of transdisciplinary approach is shown in figure 03 below.

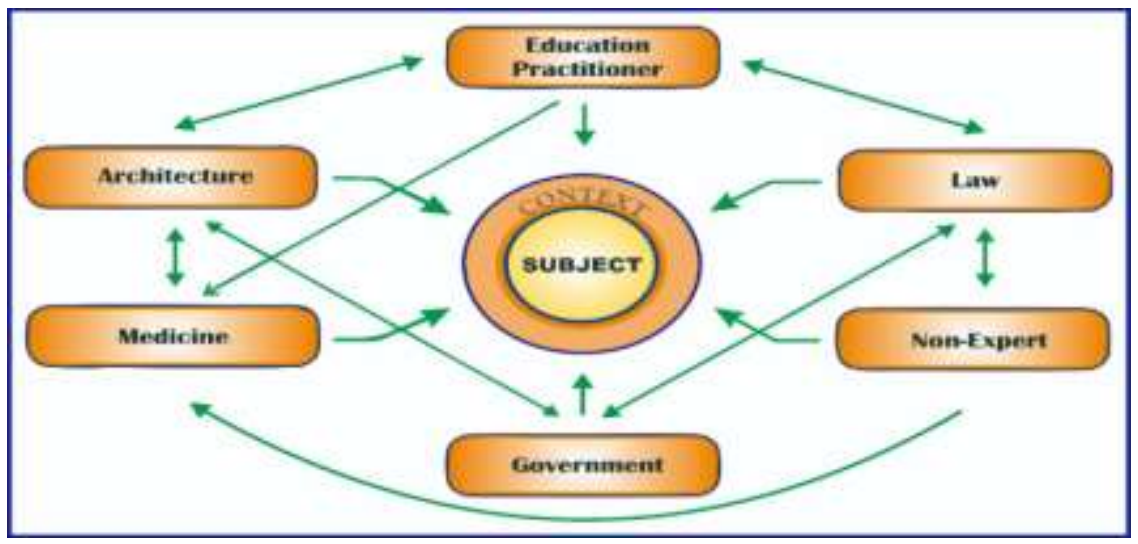

Figure 03: Transdisciplinary Approach in Team Teaching

Transdisciplinary approach was regarded as the most difficult one to be implemented in learning since it involves not only

${ }^{23}$ Batmang, "Pendekatan Transdisipliner," 44-45. 
lecturers from different disciplines, but also the experts who formally do not have academic qualification as stated at Regulation No. 14 of 2005 on the role of teachers and lecturers that teachers must possess academic qualification, competence, and certification. This reason caused the three Islamic Higher Educations (IHE) fail to implement the transdisciplinary approach within curriculum and learning.

\section{Research Development based on MIT approach}

In addition, to be used in the process of learning, MIT approach is further developed particularly by lecturers and students in their research. This can be seen in several research products produced by these three universities. The research base reinforcement for students was employed by maintaining their practical science disciplines as a theoretical framework to analyse Islamic science using various perspectives, such as Management, Communication, and medical science. Those having Islamic science disciplines were introduced to Sociology and Anthropology to strengthen their research bases.

MIT based research at three graduate schools of UIN Jakarta, UIN Yogyakarta, and UIN Malang was supported by adequate resources and learning media. The research products are: (1) neuroscience dalam Islam/ neuroscience in Islam, (2) cahaya dan Fisika dalam Al-Qur'an/ light and Physics in the Qur'an, (3) wayang khilafah/ khilafah puppets, (4) al-Qur'an dan Teori Kosmos/ the Qur' an and Cosmos Theory, and etc. Interdisciplinary and multidisciplinary research products are produced more compared to those using transdisciplinary approach, even though transdisciplinary approach in learning enables learning process to move beyond its boundaries ${ }^{24}$ since the materials used in it are discussed profoundly. Transdiscipline crosses over discipline boundaries; therefore, any problems will be able to be viewed from various disciplines and the solution will be comprehensible.

${ }^{24}$ Cucun Sunaengsih, "Pengaruh Model Pembelajaran Transdisciplinary terhadap Karakter Siswa pada Sekolah Dasar Internasional Berbasis International Baccalaureate," Mimbar Sekolah Dasar 2, no. 2 (October 30, 2015): 169, accessed March 30, 2020, https://ejournal.upi.edu/index.php/mimbar/article/view/1327. 
Within the view of transdisciplinary approach, education must be related to student's humanity and human potential developments. ${ }^{25}$ According to Seaton as quoted by Batmang, new science is required as an attempt to solve today's global issues to comprehend life problems within various levels of social systems. ${ }^{26}$ Four main issues most frequently discussed in multisectoral are: (1) human aggression, (2) human resources distribution, (3) anthropocentric worldview development, and (4) human empowerment through education. Transdisciplinary approach is needed to solve multi-sectoral global problems. ${ }^{27}$ This approach is considered as intellectual space to discuss the related, explored, and opened issues to obtain better comprehensions. The meaning of transdiscipline is similar to "transectorial" which requires cross perspective study. This approach is necessary to delve new meanings from a synergy.

On the contrary, Imam Mawardi defines transdisciplinary approach as a multi-perspective approach. ${ }^{28}$ If interdisciplinary approach attempts to integrate themes in some subjects, multidisciplinary approach assumes the discussion on a certain theme viewed from each scientific field, then transdisciplinary approach views a theme from not only the perspectives of the subject but also students' context and needs based on their talents and interests. Transdisciplinary learning involves students who share their specific skills and experience (through cross training), so that they can produce new knowledge together with others, create new integrated intellectual frameworks, not only integrate the concepts of scientific disciplines. Creating new knowledge requires collaboration. Therefore, students can combine perspectives from each value they are familiar with to build new transdisciplinary knowledge.

25 S. Said Hasan, “Transdiciplinarity dalam Pendidikan dengan Referensi Khusus pada Kurikulum," October 29, 2007, 2-3.

${ }^{26}$ Batmang, "Pendekatan Transdisipliner," 2-3.

27 Nomida Diana, Filsafat Ilmu Lanjutan (II) (Jakarta: Universitas Negeri Jakarta, 2010), 3.

28 Imam Mawardi, "Pendidikan Islam Transdisipliner dan Sumberdaya Manusia Indonesia," Jurnal Pendidikan Islam 28, no. 2 (2013): 2, accessed March 6, 2020, https://journal.uinsgd.ac.id/index.php/jpi/article/view/547. 


\section{Learning Resources Development and Network Access}

Interdisciplinary and multidisciplinary learnings at graduate schools of UIN Jakarta, UIN Yogyakarta, and UIN Malang were supported by optimal learning resources and media, including special rooms called quite room. This room was used to write and do the assignments equipped with electricity and adequate internet access. Men and women were in different rooms and controlled by CCTV camera.

Internet, such as open journal system (OJS), translation service, etc, has contributed greatly to educational world. OJS can be accessed to assist learning difficulty. The use of internet and OJS in learning is a combination between knowledge and technology. Internet is a product of the advanced of technology which gives enormous influence upon educational world. The word internet derives from Latin 'inter', which means between. Internet is a network for communicating any forms of information worldwide to be accessed quickly and easily. ${ }^{29}$

Another learning resource provided to endorse the intermulti-trans-disciplinary approaches was the library. Library, in an educational institution, is provided as literacy. Multireference library provided collections of books to support students' learning activities. Moreover, students now can search for books, theses, or journals available in the library through digital library services.

Furthermore, the interdisciplinary and multidisciplinary learnings were also supported with beautiful environment of the campus including many shady trees with benches underneath and equipped with electricity access. In addition, special rooms for lecturers were also part of learning resources that students could easily meet the lecturers for consultation or discussion. Another facility is shuttle service for professors, so that they would be able to attend classes easily and without any additional costs and energy. Therefore, the professors would be able to have more concentration on transferring their knowledge to the students.

29 Rahmat Hidayat, "Analisis Tingkat Penggunaan Internet di Kalangan Mahasiswa dan Hubungannya dalam Peningkatan Nilai Akademik," Jurnal Mediasi 2, no. 2 (December 2010): 56. 
The benefit of this research result is also strategy to optimize learning media and resources to achieve maximum results of intermulti-transdisciplinary learning. The result of this research is used as learning materials. The results of this reseach prove that educators always attempt to up-grade students' knowledge to meet current development. The research results should be nationally or internationally accredited in the form of, for instance, thesis, dissertation, or journal. Besides, the journal used needs to be relevant to the learning materials.

The research results discussed above might be easily understood by looking at the following figure on MIT learning strategy and approach:

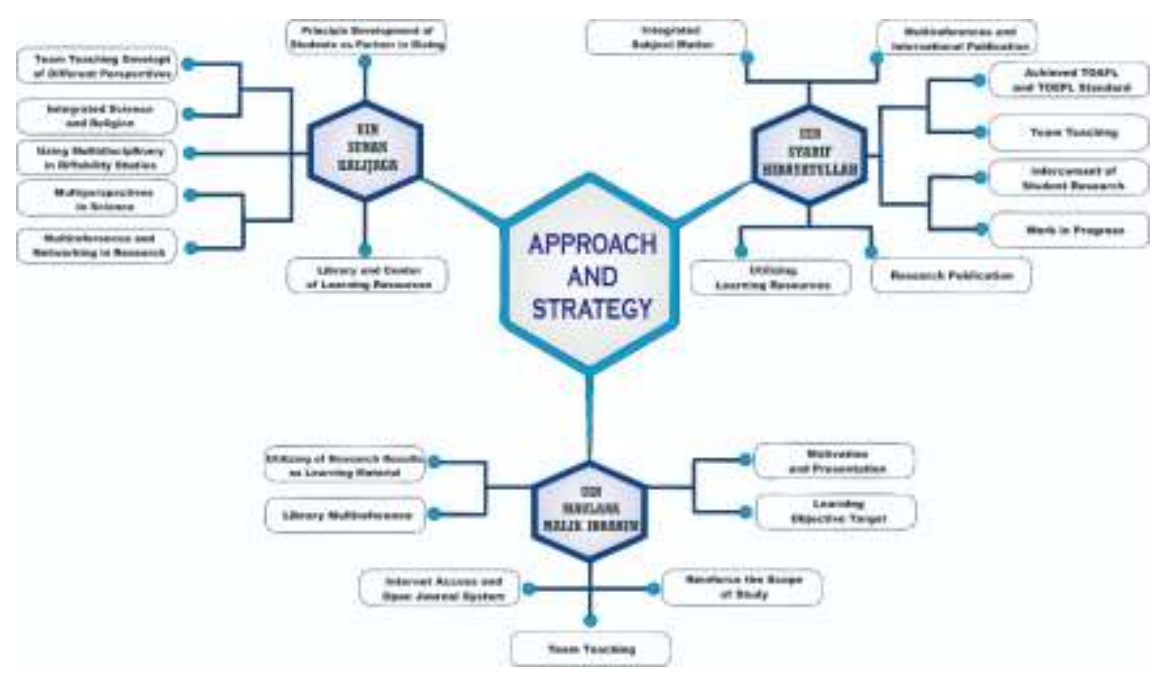

Figure 04: MIT Learning Strategy and Approach

\section{MIT Learning Outcomes based on KKNI curriculum}

Islamic and western sciences need to be integrated to complete each other, for example, Islamic Psychology which tends to be normative and Western Psychology which has rich empiric experiments but poor of values. One of the results of interdisciplinary and multidisciplinary learning at the graduate school of UIN Jakarta was interdisciplinary and multidisciplinary based dissertation. This was apparent from the titles of the works which contained the elements of MIT integration, explanation and 
analysis. One example of interesting dissertations applying interdisciplinary and multidisciplinary approach was on Islam and environment. This research discussed the difference of two regions viewed from google map. One region looked green and shady, whereas the other looked red. The findings showed in the green region, Sufism teachings as taught by the teacher was included to preserve nature. Meanwhile, the other region was a mining place and factory with excessive pollution.

Multidisciplinary and interdisciplinary approaches show separation of scientific disciplines. Both approaches have integration concept required to improve understanding of problems. Multidisciplinary approach still expresses monodiscipline aspects, so that to solve complex problems, both qualitative and quantitative solution are required. The quantitative feature indicates the integration of some sciences. The integration is the result of transdisciplinary redefinition within basic and fundamental framework or science. ${ }^{30}$

The other result of interdisciplinary and multidisciplinary learning outcomes was that students had freedom to choose research topics based on their interest. In graduate school of UIN Jakarta, the main topic of research was Islamic study but it could be developed further from various approaches and perspectives in accordance with students' concentration. Students with successful research on interdisciplinary and multidisciplinary approach would be granted studying to overseas university to develop their thesis and dissertation.

Furthermore, other research results of interdisciplinary and multidisciplinary learning outcomes at graduate school of UIN Yogyakarta included various research results and non-expert involvement in one thesis product applied in khilafah puppet (wayang). This graduate school has a study program whose students have medical (doctor) background; then the research is directed to Islamic themes and Muslim society. This is one implementation of MIT.

Suarez-Orozco and Satin-Bajaj are researchers who believe when a discipline has reached its maturity, a dynamic meta-

\footnotetext{
${ }^{30}$ Batmang, "Pendekatan Transdisipliner," 44-45.
} 
structure is required to facilitate integration and division of new discipline ${ }^{31}$ Hirsch Hadorn and others argue that in the case of neuroscience, cognitive science and education, more comprehensive understanding on learning is very important attractive thrust for a wider goal such as sustainable, economic growth, social cohesion, and personality development. Hence, in the context of education, multidisciplinary approach is utilized to answer complex questions which cannot be answered in a certain subject, but involving the present context and multi-sectoral collaboration. 32

"Integrated-interconnected" scientific paradigm developed by UIN Sunan Kalijaga needed to be divided into competencies expected from the graduates of each study program. Insight, understanding, and vision from lecturers and study program management on particularly the output produced by each study program are required to formulate the study program competence. This study program competence is substantially developed based on the vision mission, and goal of UIN Sunan Kalijaga as well as integrative-interconnective scientific framework. Study program competence produced by UIN Sunan Kalijaga was more comprehensible since it did not only include standard competence and graduate main competence, but also philosophical basis, strategic issues, study program profile, graduate competence profile, integrated-interconnected competence, and curriculum structure.

The effort to reunite Islamic sciences to modern sciences has been continuously done by UIN Yogyakarta. Each science was inseparable to the other. There was no division such as Islamic or modern sciences, but science should not be restricted for whatever the reason is. Many people are not satisfied with this controversy. Some even consider this controversy as legitimation to secularization process in Indonesia. This policy has at least obtained legitimation basis from the scientific integration-

${ }^{31}$ Andrej Flogie and Boris Abersek, "Transdisciplinary Approach of Science, Technology, Engineering and Mathematics Education," Journal of Baltic Science Education 14, no. 6 (December 1, 2015): 779.

32 Ibid., 782. 
interconnection paradigm as the ideal scientific development prototype of the university.

The conversion aiming at eliminating the dichotomy between religious and general sciences is even stuck in the dichotomic and reductionary point of view and in favor of Islamic sciences rather than those come from western tradition. However, it is apparent here that the integration-interconnection paradigm discourse for the last 5 years had been in practice at theoretical level only.

Some points taken from integration-interconnection paradigm are (1) in philosophical domain, each subject must be given fundamental existential value related to other scientific disciplines and in relation to humanistic values; (2) in material domain, integration-interconnection is about the process of integrating universal and particularly Islamic truth values into general sciences such as philosophy, anthropology, etc. Such integrationinterconnection implementation could form integration model into curriculum; selecting names for the courses which show the relationship between general and Islamic sciences; and integration model into the course themes; (3) in methodological domain, that is when one discipline of science is integrated dan interconnected to another, such as philosophy and Islamic values; (4) in strategic domain, which is the application and practical domain from integration-interconnection learning process. In practice, many argue that the integration-interconnection paradigm developed by UIN Yogyakarta still has limitations, since it tends to focus only on epistemological and ideological critic construction, not covering the four principles above yet. ${ }^{33}$

Meanwhile, graduate school of UIN Maulana Malik Ibrahim Malang has implemented interdisciplinary learning to have graduates with strong aqidah (faith), deep spirituality, good moral, broad knowledge, develop and empower the society, and are able to formulate new concepts in integrating knowledge on Islam and Indonesia. The implementation of interdisciplinary approach in

33 Luthfi Hadi Aminuddin, "Integrasi Ilmu dan Agama: Studi Atas Paradigma Integratif Interkonektif UIN Sunan Kalijaga Yogjakarta," Kodifikasia: Jurnal Penelitian Islam 4, no. 1 (December 1, 2010): 210, accessed April 30, 2020, http://jurnal.iainponorogo.ac.id/index.php/kodifikasia/article/view/746. 
learning aims to have UIN Maliki Malang graduate capable of developing sciences based on interdisciplinary study either in the form of teaching, research, or community service. Therefore, the learning outcomes are students' works as contributions to educational world.

The learning outcomes based on MIT approach can be found at students' or lecturers' works. The works which contain intermulti-transdisciplinary approach combine one since to another. Two examples of students' theses are the influence of memorizing Al-Qur'an tradition toward integrative thematic learning achievement at SDI As-Salam Malang and the internalization of students' spiritual attitude through guiding and counselling programs in MAN 1 Kota Malang. Lecturers' works related to MIT approach include Physics in the Qur'an, Mathematics in the Qur'an, Embryology in the Qur'an, and Dust of the Universe.

The research results discussed above can be understood easily through the figure below:

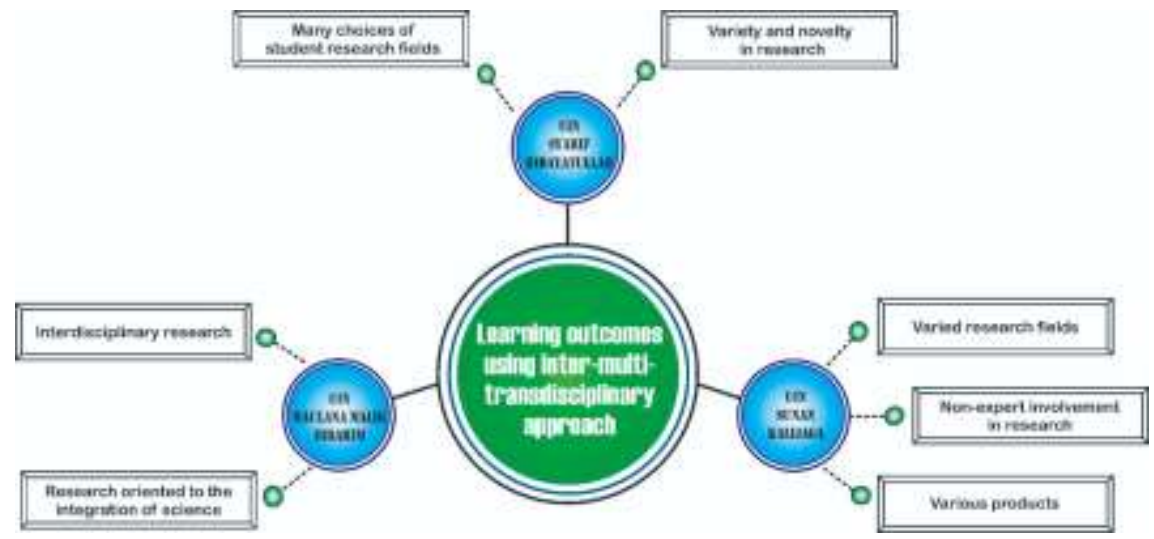

Figure 05: MIT approach learning outcomes

\section{Conclusion}

It can be concluded from this study that the strategies and approaches employed in the MIT teaching at graduate schools of three different Islamic higher educations are in (1) integrating MIT-based thematic courses, (2) Team Teaching to reinforce MIT study, (3) research development using MIT approach, (4) developing learning resources and network access, and (5) MIT 
Learning Outcomes based on KKNI curriculum. The implementation of MIT approach is dependent on the paradigms and perspectives of lecturers and policy makers at each graduate schools; thus, this brings about various and competitive results in producing new products on education. The three Islamic universities have successfully implemented the multidisciplinary and interdisciplinary approaches with their curriculum and teaching practices. Nevertheless, transdisciplinary approach has not yet been found in learning. These universities have not involved non-experts and non-academic staff as their research subjects and teaching but as the objects of the study.

\section{References}

Abdullah, M. Amin, Abdul Munir Mulkhan, Machasin, Musa Asy'arie, Khoiruddin Nasution, Hamim Ilyas, and Fahruddin Faiz. Praksis Paradgima Integrasi-Interkoneksi dan Transfomasi Islamic Studies of UIN Sunan Kalijaga. Yogyakarta: PPs UIN Sunan Kalijaga Press, 2014.

Academic team. "Kurikulum." PPS UIN Sunan Kalijaga. Accessed February 6, 2020. http://pps.uin-suka.ac.id/id/akademik/ kurikulum.html.

Aminuddin, Luthfi Hadi. “Integrasi Ilmu dan Agama: Studi Atas Paradigma Integratif Interkonektif UIN Sunan Kalijaga Yogjakarta." Kodifikasia: Jurnal Penelitian Islam 4, no. 1 (December 1, 2010): 181-214. Accessed April 30, 2020. http://jurnal.iainponorogo.ac.id/index.php/kodifikasia/article/ view/746.

Batmang. "Pendekatan Transdisipliner (Suatu Alternatif Pemecahan Masalah Pendidikan)." Al-TA'DIB 9, no. 2 (July 1, 2016): 44-54. Accessed March 30, 2020. http://ejournal. iainkendari.ac.id/al-tadib/article/view/512.

Bogdan, Robert. Participant Observation in Organizational Setting.

New York: Syracuse University Press, 1972.

Bogdan, Robert, and S.J. Taylor. Pengantar Metode Penelitian Kualitatif. Translated by Arief Furchan. Surabaya: Usaha Nasonal, 1992. 
Chaeruman, Uwes A. "Memahami Konsep Trandisiplineritas dan Pendidikan Trandisipliner." Paper presented at the Philosophy course at Doctorate degree of Education Technology, Graduate Program, State University of Jakarta, Jakarta, December 2010.

Diana, Nomida. Filsafat Ilmu Lanjutan (II). Jakarta: Universitas Negeri Jakarta, 2010.

Flogie, Andrej, and Boris Abersek. "Transdisciplinary Approach of Science, Technology, Engineering and Mathematics Education." Journal of Baltic Science Education 14, no. 6 (December 1, 2015): 779-790.

d'Hainaut, Louis. "International Symposium on Interdisciplinarity in General Education." 9-12. Unesco Headquarters, 1986.

Hasan, S. Said. "Transdiciplinarity dalam Pendidikan dengan Referensi Khusus pada Kurikulum." Paper presented at the Transdiciplinarity Seminar at UIN, October 29, 2007.

Hidayat, Rahmat. "Analisis Tingkat Penggunaan Internet di Kalangan Mahasiswa dan Hubungannya dalam Peningkatan Nilai Akademik." Jurnal Mediasi 2, no. 2 (December 2010): 5563.

Mawardi, Imam. "Pendidikan Islam Transdisipliner Dan Sumberdaya Manusia Indonesia." Jurnal Pendidikan Islam 28, no. 2 (2013): 253-268. Accessed March 6, 2020. https://journal.uinsgd.ac.id/index.php/jpi/article/view/547.

van Melesen, A.G.M. Ilmu Pengetahuan dan Tanggungjawab Kita. Translated by K Bertengs. Jakarta: Gramedia, 1985.

Miles, Matthew B., A. Michael Huberman, and UI Team. Analisis

Data Kualitatif. 1st ed. Jakarta: Universitas Indonesia, 1992.

Prentice, A.E. "Introduction." In Information Science-The Interdisciplinary Context, edited by J.M. Pemberton and A.E. Prentice. New York: Neal-Schumen Publisher, 1990.

Razi, Pakhur. "Hubungan Motivasi dengan Kerja Ilmiah Siswa dalam Pembelajaran Menggunakan Virtual Laboratorium Kelas X SMAN Kota Padang." Jurnal Informasi dan Pendidikan 6, no. 2 (2013): 120-134.

Robinson, Chase S. Para Pembentuk Sejarah Peradabah Islam Seribu Tahun Pertama. 1st ed. Ciputat: Pustaka Alvabet, 2019. 
Root-Bernstein, Robert, and Michele Root-Bernstein. "Artistic Scientists and Scientific Artists: The Link Between Polymathy and Creativity." In Creativity: From Potential to Realization, edited by R. J. Sternberg, E. L. Grigorenko, and J. L. Singer, 127-151. Washington, DC, US: American Psychological Association, 2004.

Rosdiana A. Bakar. "Konsep Pendidikan Muhammad Quthb." Ihya' Al-'Arabiyyah 5, no. 1 (2015): 26-38. http://ejournalpba. org/index.php/ihya/article/view/2/2.

Sudikan, Setya Yuwana. "Pendekatan Interdisipliner, Multidisipliner, dan Transdisipliner dalam Studi Sastra." Paramasastra 2, no. 1 (March 1, 2015): 4-12. Accessed July 6, 2020. https://journal.unesa.ac.id/index.php/paramasastra/ article/view/1496.

Sunaengsih, Cucun. "Pengaruh Model Pembelajaran Transdisciplinary terhadap Karakter Siswa pada Sekolah Dasar Internasional Berbasis International Baccalaureate." Mimbar Sekolah Dasar 2, no. 2 (October 30, 2015): 167-174. Accessed March 30, 2020. https://ejournal.upi.edu/index.php/ mimbar/article/view/1327.

Vaideanu, G., and Unesco-CEPES. Interdisciplinarity In Higher Education. Bucharest: Unesco-CEPES, 1983.

Wood, Phil, and Graham Butt. "Exploring the Use of Complexity Theory and Action Research as Frameworks for Curriculum Change." Journal of Curriculum Studies 46, no. 5 (September 3, 2014): 676-696. Accessed February 6, 2020. https://doi.org/ 10.1080/00220272.2014.921840.

Graduate School Academic Handbook 2015-2019. UIN Syarif Hidayatullah Jakarta, 2015.

Precidential Regulation (Perpres) No. 8 of 2012 on Indonesian National Qualification Framework (Kerangka Kualifikasi Nasional Indonesia/KKNI), 2012.

Regulation of the Ministry of Research and Technology, Higher Education Directory (Permenristekdikti) No. 44 of 2015 on Higher Education National Standard (Standar Nasional Pendidikan Tinggi/SNPT), 2015. 